Università degli Studi di Salerno

Centro di Economia del Lavoro e di Politica Economica

Maria Rosaria Garofalo, Annamaria Nese

UNIVERSITA' DEGLI STUDI DI SALERNO

C.E.L.P.E.

Social Preferences and the Third Sector: Looking for a Microeconomic Foundation of the Local Development Path

\author{
Corresponding author: \\ anese@unisa.it
}

Discussion Paper 110 
Scientific Commitee:

Adalgiso Amendola, Floro Ernesto Caroleo, Cesare Imbriani, Pasquale Persico

\section{C.E.L.P.E}

Centro di Ricerca Interdipartimentale di Economia del Lavoro e di Politica Economica Università degli Studi di Salerno

Via Ponte Don Melillo, 84084 Fisciano, I- Italy

http://www.celpe.unisa.it

E-mail: celpe@unisa.it 


\section{Indice}

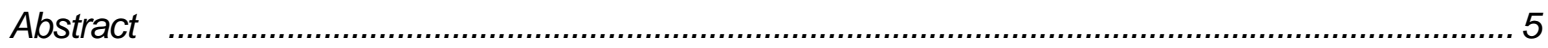

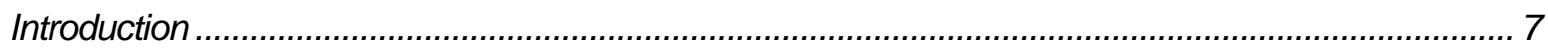

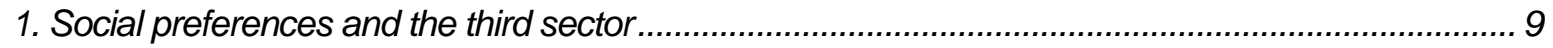

1.1 Altruistic preferences, preferences based upon reciprocity or upon inequity aversion ..................10

1.2 Endogeneity and transmission of social preferences: the role of the institutions........................11

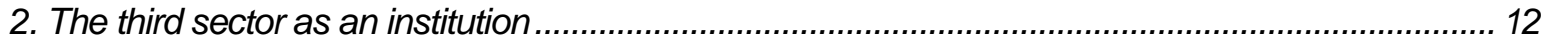

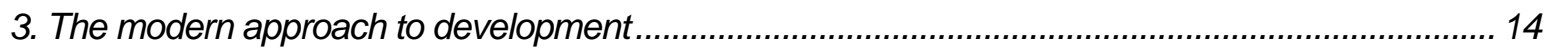

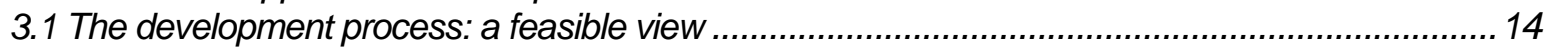

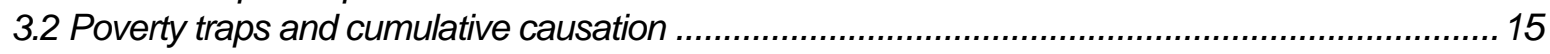

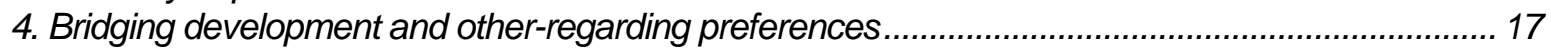

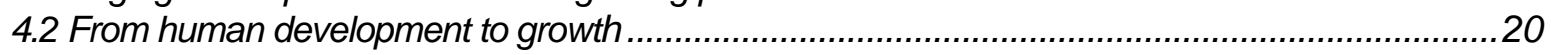

5. Concluding remarks: social preferences, local development and the role of the third sector........... 21

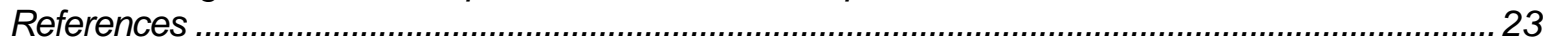




\title{
Social Preferences and the Third Sector: Looking for a Microeconomic Foundation of the Local Development Path*
}

\author{
Maria Rosaria Garofalo, Annamaria Nese \\ UNIVERSITA' DEGLI STUDI DI SALERNO \\ C.E.L.P.E.
}

\begin{abstract}
The aim of the paper is to endorse the principle, recurrent in non-profit literature, that the third sector is an institution that supports the development process of economic systems. The third sector is considered as an institution that "favors, transmits and cements" the role of social preferences in a given economy and, in this way, it contributes to development. The paper thus considers two stances taken up in economic theory: (i) the theory of social preferences; (ii) the modern theory of development. These two stances do not exclusively and specifically refer to the third sector, and they generally follow parallel paths, rarely being aware of each other: in the paper, the third sector is assumed to form a bridge between them in that social preferences are supposed to be one of the driving forces in the change process of an economy.
\end{abstract}

Keywords: endogenous social preferences, third sector, local development.

JEL classification: D63, O12, O17, P19, A13

Acknowledgements: We are grateful to an anonymous referee for his helpful comments. A preliminary version of this paper as been published as ISSAN Working Paper no. 26, University of Trento. 


\section{Introduction}

Until the 1970s, in almost all European countries advocacy organizations prevail, often operating in autonomy with respect to the welfare authorities. Since the ' 80 s and the ' 90 s, coherent with the processes reforming welfare, different forms of collaboration between the NPOs and governments emerge and get stronger, according to the decentralization aim of each country's welfare policy (Borzaga \& Santuari, 2000). In particular, since the 1990s the third sector as a whole has not only strengthened its relative economic weight in terms of GNP and employment (Salomon \& Anheier, 1999), but it has also diversified its role, its organizational forms and its relations with the state and the market (Ben-Her \& Gui, 2003).

With regard to this historical path, the aim of the paper is to offer a further theoretical cue to highlight the role of the third sector - as an institution alongside the state and the market- in the development of Western European countries. The third sector is considered here as an institution that "favors, transmits and cements" the role of social preferences in a given economy and, in this way, it contributes to development.

Firstly, the paper focuses on the microeconomic foundations of the third sector's emergence and sustainability; secondly, it defines the concept of institution useful for the analysis of economic performance and development; and finally, it deals with the complementarities of the institutions operating within a given economy. Even if many different organizational forms populate the third sector, the latter is defined here according to the criterion of the main activity's sector (Ben-Her \& Gui, 2003): in particular, the paper refers to the NPOs producing and delivering welfare services and goods for social purposes.

The starting point of this research is thus to consider microeconomic foundations of the third sector, stressing the supply-side aspect. In analyzing the motivations of individuals engaged in voluntary non-profit activities, the theoretical reference is the literature on non-selfish preferences, and, more specifically, the works in experimental economics (Gintis, Bowles, Boyd \& Fehr, 2005) focusing on the possible outcomes of social interaction when the population is composed of individuals with heterogeneous preferences (altruists, egoists, conditional co-operators, etc.). An outcome shared by most evidence is that when a population is mainly composed of free riders, also those inclined to cooperation end by adopting selfish behavior (either because reciprocity feelings prevail or because isolated cooperative actions are considered useless and too costly). In a more general way (and closer to our interests), it can be said that "the more trust we put into institutions relying on the principle of the exchange of equivalents (i.e. the market), the more cultural traits and behavior norms in the society will reflect that principle" (Zamagni, 2005; the Authors' translation). 
On the contrary, the third sector represents the institution that can favor the emergence of cooperative behaviors, by organizing and sustaining them through new laws and new organizational forms.

Individual behavior in the non-profit activities (e.g. voluntary services, donations, etc.) reveals that the motivations behind human actions are not only selfish, but they often reflect other values, such as fraternity, reciprocity, altruism, and these values permit other forms of social interactions, different from those based on the exchange of equivalents (as in the market) or on the compulsory contribution (as between citizens and the state) (Zamagni, 2005). This kind of human behavior, recognized as useful to society, is institutionalized and sustained by new laws, new organizational forms and new expectations (in that it has become standard in certain settings). The third sector can be considered as an institution in that it defines the environment (or the broad system of norms, beliefs and "rules of the game") in which NPOs can operate. The institution concept referred to here thus corresponds to Schotter's (1986) "the way the game is played", to Nelson and Sampat's (2001) "social technologies" and to North's (1990) "formal and informal rules". More specifically, institutions shape productive pathways of "doing things" in contests involving human interaction (in the language of transaction costs, institutions define less costly ways of doing certain activities, thus making such activities more attractive and easy). In this way institutions become a development factor.

Finally, the paper focuses on the contribution of the non-profit sector to economic growth and development. It considers the NPOs' capacity to produce new kinds of goods and services: for example, homes for battered women, social work for refuges and immigrants, senior services, infant schools, or, more generally, services reflecting demographic changes in the population (e.g., population aging, larger female participation in the labor market, etc.). The third sector is also innovative by implementing new means of production, in particular new factor combinations and different organizational forms that foster inclination to cooperate, solidarity, sense of dignity and self-determination (e.g., favoring social inclusion or through governance models enhancing stakeholders' participation in decision-making processes, etc.).

In analyzing the contribution of the third sector to the development of an economy, the theoretical reference is the recent literature on development, focusing on the obstacles to the process of structural change of an economy and to the active participation of all agents in all markets, obstacles characterizing "poverty trap" phenomena (Bowles, 2003; Durlauf, 2006; Hoff, 2000).

The outlay of the paper is as follows: the first section briefly reviews the theory of social preferences; the second section deals with the concept of institution; the third section introduces recent models in the development theory also to make non-economist readers more familiar with them. Given the extensive literature on non-selfish preferences and on development, these two theories will not be dealt with comprehensively, but will be selected in a way consistent with the idea being developed. In economics, these theories do not exclusively and specifically refer to the third sector. They generally 
follow parallel paths and rarely are aware of each other: in the paper, the third sector is assumed to form a bridge between them. The last issue is addressed in more detail in Section 4 which discusses whether and how social preferences, and their agglomeration, can operate in favor of an economy's local development. Only if these conditions are met, can the nonprofit sector play an important role in the development of the advanced economies.

Section 5 draws some concluding remarks.

\section{Social preferences and the third sector}

Traditional theories of non-profit organizations (e.g., Hansman, 1986; Weisbrod, 1986) have mainly focused on the individual motivations leading to consume goods and services offered by the NPOs instead of those offered by the market or by the state. These theories, focusing on the demand-side aspect, have recognized a "residual" role to the third sector, conceived as a solution to the well-known forms of market and state failures. On the contrary, supply-side oriented theories (James, 1986; Young, 1980; RoseAckerman, 1996) have had the merit of underlining that the NPOs are the result of autonomous behavior patterns, independent of market and state failures (Zamagni, 2002). For example, Rose-Ackerman (1996), with reference to altruism and non-profit entrepreneurship, has argued for the existence of motivations driving individual behavior that cannot be understood within the standard neoclassical framework but that "require a richer conception of individual utility function".

A further important issue is whether the non-profit sector effectively selects and reinforces non-selfish preferences in the society. Whether individuals engaged in voluntary non-profit activities are motivated by altruism, reciprocity, solidarity or, simply, by a wish of social visibility, they all attach more importance to a social mission than to personal gain (Young, 1999; Sacco \& Zarri, 2006). When these organizations are successful in coordinating human actions to the achievement of a social aim, evidently they encourage cooperative behavior and the emergence of social trust. Putnam (1995, p. 2), for example, underlines that "networks of civic engagement foster study norms of generalized reciprocity and encourage the emergence of social trust. Such networks facilitate coordination and communication, amplify reputations and thus allow dilemmas of collective action to be resolved".

Relying on evidence drawn from the 1991 World Value Survey, Putnam (1995) reports a positive correlation between social trust and civic engagement both at a micro and at a macro level: firstly, members of associations are more likely to participate in politics, to spend time with neighbors, and to express more social trust than non-members; secondly, density of associational membership and social trust are found to be significantly correlated across 35 countries considered in the same Survey. 
As will be seen in more detail below, the theoretical research and the evidence produced in recent years about social preferences can be particularly useful in order to address the issue of emergence and sustainability of non-selfish (or social) preferences in a society: several laboratory experiments not only support new hypotheses on individual behavior (altruism, reciprocity, inequity aversion, other than egoism) but they also point out that the presence of individuals with heterogeneous preferences can affect the functioning of competition, cooperation, and the outcome of collective actions .

Furthermore, a lot of studies concerning social capital (in particular, the contribution of Coleman, 1988) have underlined that social trust and cooperative behavior improve the effectiveness of institutions and, at the same time, are sustained by "high quality" institutions (e.g., Tabellini, 2007).

Section 1.1 briefly reviews the literature on social preferences; Section 1.2 discusses issues relating to the endogenous formation and transmission of preferences, highlighting the role played by all the institutions that influence an economy's performance.

\subsection{Altruistic preferences, preferences based upon reciprocity or upon inequity aversion}

Social preferences may correspond to reciprocity-based preferences, to inequity aversion or to altruistic preferences. Conditional co-operators are ready to cooperate if others cooperate, while strong reciprocators may also punish (at personal cost, if necessary) those unwilling to cooperate (Rabin, 1993; Levine, 1998; Fehr \& Gachter, 2000; Falk \& Fischbacher, 2005; Fishbacher and Gachter, 2008). Punishment is driven mainly by a 'feeling of anger' towards those performing 'unfair' actions. Individuals with preferences of inequity aversion pursue the fair distribution of resources (Fehr \& Schmidt, 1999; Bolton \& Ockenfels, 2000). Finally, an unconditional altruist is willing to cooperate independently of the contribution pattern of others (Becker, 1974).

Theoretical research has supported various laboratory experiments conducted to test the explanatory capacity of models based upon non-selfish preferences. In particular, empirical evidence based on public goods games show that many individuals are ready to cooperate, at least as long as the others do so, while some others are ready to punish (at a personal cost) "free riders" (Andreoni, 1988; Fehr \& Gachter, 2000; Fischbacher, Gachter, \& Fehr, 2001). These results are interesting in that if all the agents were selfish, no one would decide to contribute or punish.

If the literature based on laboratory trials abounds, many examples are also taken from real life: following Reingen (1982), Kahan (2005) stresses that non selfish individuals reciprocate the disposition of others in giving, or not, to charity; Bowles and Gintis (2005, p. 381) maintain that individual motivations supporting peer monitoring and other aspects of community governance are captured by strong reciprocity, which is a "predisposition to cooperate in a collective enterprise, and a predisposition to punish those who violate norms, 
both of which are individually costly but conductive to strong social capital". Finally, relying on evidence from twenty firms in Lombardy, Sacconi and Grimalda (2005) highlight the role of "conformist preferences" - a motivational structure similar to the one proposed by the models of reciprocity - in the creation and sustainability of social enterprises.

A further task is to analyze the social and political repercussions generated by social preferences. More specifically, it is important to analyze the results of the interaction among individuals with different preferences (social or egoistic) while outlining possible differences from the results based on the neoclassical paradigm of self-regarding preferences.

Evidence from public goods games has shown that when players are given the possibility of punishing free riders, they often do it, and thus almost all players end up by contributing (Fehr \& Gachter, 2000). However, the preference-type composition of groups affects the contribution level and the contribution path systematically (Kurzman \& Houser, 2005; Fishbacher \& Gachter, 2008): e.g., groups with more co-operators exhibit higher cooperation levels than groups with more free riders. This is why, in a highly cooperative cultural context, punishing those who do not cooperate is not a costly action; conversely, if cooperation is not widespread, punishing those who do not cooperate entails high costs, and strong reciprocators end up by following the majority and adopting selfish behavior (Bowles \& Gintis, 2005).

An important issue for our analysis is to understand the influence that the institutions can exert on individual behavior and on the effectiveness of rules.

\subsection{Endogeneity and transmission of social preferences: the role of the institutions}

If in many cases the assumptions of egoistic preferences in the neoclassical paradigm seem unsuited to describing individual behaviors, the same applies to the assumption concerning exogenous preferences. Bowles (1998) analyses the factors affecting the development and transmission of individual preferences. He finds that economic institutions affect the structure of social relations because they modify the desirability of certain behaviors: for example, behaviors aimed at building a good reputation for oneself, and ethical and moral principles in general, perform a more important role in the case of market failures, whereas complete, perfectly functioning markets reduce their desirability. Moreover, economic institutions, together with technology, determine work types and modes. Finally, the values and behaviors induced by a society's economic institutions as described here are transmitted from generation to generation through education patterns imparted to children by their parents. In this process, the action of parents is often supplemented (and sometimes replaced) by that of the school system, which helps to spread the emerging cultural model at a particular stage of society's development.

Bowles' analysis of preferences formation and transmission gives rise to some important policy guidelines: first, and above all, the endogenous nature of preferences must be taken into account when the effects of laws and 
policies are assessed; secondly, new, socially desirable behavioral models can be introduced by means of educational campaigns or rules stigmatizing antisocial behavior.

The impact of social, legal and economic factors on the formation of preferences has been evidenced by several laboratory experiments (for a more detailed analysis, see Ostrom, 2005; Kahan, 2005; Bowles \& Gintis, 2005) and real-life cases. Fehr and Fischbacher (2005), for example, underline that "if people believe that cheating on taxes, corruption, or abuses of the welfare state are widespread, they themselves are more likely to cheat...it is therefore important that public policy prevents the initial unravelling of civic duties...(p. 167)". Tabellini (2007), using data on European regions, shows that culture (measured by trust, respect for others, and confidence in individual self-determination), recognized as an important and lasting determinant of economic performance, is strongly correlated with the quality of institutions. A likely explanation for the latter result is that democratic institutions - in all fields, economy, politics, organizations, etc. provide a feeling of inclusion, dignity, self-determination in that they emphasize participation rights in decision-making processes (Frey, Benz \& Stutzer, 2004). At the same time, culture affects the functioning of institutions: for example, Putnam (1993) shows how same formal rules have different effectiveness in Italian regions characterized by different social capital.

The analysis of preference formation and transmission carried out in recent years thus stresses the complementarities among market, state, and communities ("by a community, we mean a group of people who interact directly, frequently, and in multi-faceted ways", Bowles \& Gintis, 20005, p. 381). In particular, Bowles and Gintis (2005) outline that when individuals cooperate in their neighborhoods, in professional and business networks, in social organizations etc., they not only spread social desirable behavioral models but they also contribute to solving problems connected to state and market failures through mutual monitoring and the punishment of antisocial behavior. At the same time, if communities are to function well, they require an adequate legal and governmental context.

\section{The third sector as an institution}

Current debate still lacks a general and shared definition of 'institution'. Among different definitions of institutions (a review is in Nelson \& Sampat, 2001), referred to here are those most suitable for conceptualizing the third sector as a new institution contributing to economic growth and development.

North (1990) and North and Denzau (1994), for example, define institutions as 'rules' and classify them as "formal" - when they consist of the entire legal framework of an economy - and "informal" - when they consist of all the social norms, ethical values, shared mental models, ideologies and habits. The crucial aspect of this approach is the role attributed to the informal level. More specifically, it is the combination between the formal and informal level of an institutional framework that determines its effectiveness: the formal 
level, for instance, shapes the interaction with public bodies, as evidenced by the process of welfare reform across Europe; in addition, the informal level affects the way in which private agents perceive and take advantage of the transaction opportunities created by (new) formal rules, modify their aspirations, are inclined to innovate, cooperate, etc.

Another point of reference here is Nelson and Sampat's (2001) proposal, whereby the concept of institutions is tied to standardized patterns of human behavior ("social technologies") and to the factors supporting these patterns. Nelson and Sampat state that the processes underlying economic activities require not only "physical "technologies, but also "social" technologies . More specifically, physical technologies describe technical routines (involving specific materials and machineries) for "doing things", while social technologies concern standard patterns of behavior involving the coordination of human actions (e.g. any division of labor, mode of labor coordination, etc.). These patterns emerge as easier and less costly "ways of doing things" and, when they are recognized as useful to society, they are institutionalized and sustained by new laws, new organizational forms and new expectations (in that they have become standard behavior in certain settings) .

According to the above-mentioned definitions, the third sector is an institution of an economy because it corresponds to laws, organizational forms, cultural beliefs and norms that make easier (or less costly) the production and delivery of goods and services for social aims. For example, in a recent extension of transaction cost theory analyzing the importance of nonprofits in an economy, Valentinov (2007) emphasizes that individuals, even if inclined to voluntary work, generally worry themselves with the problems of who deserves more assistance and whether the resources have been allocated efficiently. Non-profit organizations help reduce transaction costs (which in this case are mainly due to limited information), and this role is even more important in relation to small contributions (e.g., consider the fundraising activities that permits the collection of small contributions which otherwise would not be received).

More generally, the third sector includes "new laws", "new models of interactions", "new models of organization of work" that foster inclination to cooperate, sense of dignity and self-determination (e.g., favoring social inclusion or through governance models enhancing stakeholders' participation in decision-making processes, etc.).

In this way, the third sector becomes an institution that favors the emergence of social preferences and promotes their diffusion through the introduction of models of production/allocation/exchange (recognized as useful and needed by society) consistent with those preferences. As the example given in the previous section have shown (for example, Gachter \& Fishbacher, 2000) the emergence of such behavioral patterns may promote a virtuous circle since cooperative behavior becomes easier in more cooperative contests. 


\section{The modern approach to development}

This section deals with modern theories of development (Hoff \& Stiglitz, 2000; Ray, 2000), with particular reference to the main obstacles (characterizing "poverty trap" phenomena) to the process of structural change of an economy, to social inclusion and to democratic participation of all agents in all markets.

These theories do not provide a general theoretical framework but offer multiple explanations for the fact that agents in backward areas "do not always avail themselves of the best opportunities afforded to them" (Banerjee \& Duflo, 2005). The methodological approach of these models seems relevant in that it stresses the importance of the economic and institutional context for both individual choice models (i.e., the formation of preferences, productive and allocative patterns, distributive rules, etc.) and models of interaction between individual agents (i.e., cooperation, coordination, defection, etc.), as well as the impact of individual choices and their interactions on an economy's various markets.

The following subsections refer, respectively, to a definition of development process in which the third sector can play an ever-increasing role in the future (3.1) and to the main factors characterizing poverty trap phenomena (3.2).

\subsection{The development process: a feasible view}

A first step consists in clarifying the definition of development referred to in the paper.

In Schumpeter's theory, to which entrepreneurship theories of the third sector relate (Young, 1980), development is defined as the process of "carrying out new combinations" in the process of production" where the concept of "new combinations" refers to the introduction of new goods and services, new combinations of productive factors, new organizational forms, the activation of new markets and linkages between them.

More generally, development corresponds to a process of structural change of an economy and to the consequent improvement of individual living conditions, that can be measured not only as having a higher purchasing power (on average) ex post but also as the broadening and the diversification of individual choice opportunities ex ante (Sen,1999; Hoff, 2000; Bardhan, 2004).

The long-term path of Western European countries shows that the social dimension of development is important (Salvini \& Mira D'Ercole, 2003). More specifically, the social dimension of development is important because the widening of choice opportunities requires, in order to be effective, that change be made not only to the rules of income redistribution ex post (money transfers), but also to the rules on access to markets ex ante (labor, capital, education, knowledge, etc.) (Rodrik , Subramanian. \& Trebbi, 2004; Engermann \& Sokoloff, 2000; Acemoglu \& Robinson, 2000).

In order to explain the long-term path of an economy and the differences between countries and regions, it is interesting to consider Ray's (2000, p.8) 
proposal of a 'methodological frontier', focusing on the assumption that initial conditions or individual expectations are relevant. Ray's key idea is that underdevelopment should be considered "not as a failure of some fundamental economic parameters or socio-economic values, but as an interacting 'equilibrium' that hangs together, precipitated by expectational inertia or by historical conditions". This approach implies, on the one hand, that convergence across countries is not an automatic outcome, and on the other, that there are no 'fundamental' differences among an economy's agents such to make them more or less willing to save, invest, innovate, cooperate, etc. In short, the idea is that these behaviors are related to the history of a country (for instance, to the inequality of initial conditions), or to individual expectations, motivations and cultural beliefs, which include how individual agents shape their aspirations and perceptions of opportunities and if they mutually coordinate their investments.

A hypothesis which seems particularly suited to explaining the activation and sustainability of an economy's change process has been recently suggested by Ranis, Boozer, Stewart \& Suri (2004). They focus on the existence of a two-way causation between economic growth (EG) and human development (HD), as represented below.

\section{Economic Growth $\leftrightarrow$ Human Development}

The direction running from growth to development evidences the proportion of income spent on the pursuit of social goals which improve human development. The direction from development to growth evidences that improved human development continues to support the growth process..

Ranis et al. (2004) introduce two novel features with respect to both new growth models and the Human Development Index approach (according to which high/low EG corresponds to high/low HD). The first is that HD is no longer the ultimate purpose of growth, nor is it a consumption good once subsistence has been accomplished. The second novelty is that HD is not a set of indicators (literacy, health, life expectancy) selected according to a restrictive view of Sen's (1999) capabilities. HD therefore represents the ability and effective freedom of diverse agents to lead "full lives" centered on subjective and ethnocentric cultural values and moral norms.

This bidirectional causation between EG and HD can activate virtuous or vicious circles according to the system's initial conditions and to the real transmission channels. More specifically, a virtuous circle, to be effective, requires a well-defined institutional asset in which, in our opinion, the third sector can become ever more important in that it promotes and sustains individual capabilities.

\subsection{Poverty traps and cumulative causation}

In light of the above-mentioned definition, the long-term path of an economy can be explained in several different ways. With particular reference to the approach of the modern theory of development, only some models of poverty 
traps will be considered here. They will explain why agents do not always make the best use of resources implementing innovative models (whereas innovative decisions represent the "driving force" of a change in an economy). It follows that the so-called "propagation mechanisms" of the change are also slackened or obstructed (whereas the coordination of investment decision, the activation of new markets and their linkages, etc. represent the "propagation mechanisms").

Applying a cross-reference to these models makes it possible to identify the following theoretical, methodological and policy 'core'.

(i) From a theoretical perspective, the starting point is the assumption that the 'trap' is not ascribable to the agents' insufficient effort, as if the institutional and economic context were irrelevant.

(ii) From a methodological point of view, these models rely on the cumulative causation mechanism (Hirschmann, 1958; Myrdal, 1968; Venables \& Burgess, 2004), which may trigger a virtuous or vicious circle depending on the relevant economic and institutional context. As widely known, this circle comprises a 'driving force' which identifies the necessary conditions for new investments to be launched in any economy. This circle also comprises a 'mechanism of propagation' which identifies sufficient conditions for new investments to increase and diversify transactions on the economy's various markets, and to generate self-reinforcing development paths. The positive or negative outcome of the development path depends on both thick market effects and the nature of the psychological motivations and cultural beliefs that shape economic behavior. This mechanism of cumulative causation suggests a methodological framework able to explain whether and how social preferences, transmitted by NPOs at local level, exert an impact on an economy's development path: as will be seen in more detail in Section 4 , in our opinion, social preferences constitute the "driving force", while the creation and the sustainability of social markets are the "mechanisms of propagation".

(iii) In terms of policy approach, poverty trap phenomena are considered to be cases which give legitimacy to policy interventionism. However, this does not necessarily or exclusively entail government interventionism; rather, it requires the coordination of policy makers with private agents operating at different levels or in different sectors of an economy (Matsuyama, 1996). This can be defined as a coordinated institutional system, which is one of the novelties of welfare reform in EU.

More specifically, the taxonomy of poverty trap models, recently drawn up by Bowles et al., identifies three classes of models. The first class is based on the hypothesis of a 'critical threshold' (Azariadis \& Drazen, 1990) in capital stock (physical, human or social) which enables an economy to start its development path, or otherwise. It is meaningful to consider the consequences of low human capital stock (the driving force) on agents' education choices (the mechanism of propagation), which in turn affect longrun equilibrium. The "vicious circle" consists of the fact that the low human capital stock reduces the intentions of both firms and families to innovate or invest: more specifically, there are scant opportunities for firms to shift from traditional to innovative activities or sectors, so that firms are not encouraged 
to innovate; in turn, families do not invest in education because the possibilities of finding appropriate jobs are low (with high "search costs").

A second class of models deals with the role played by institutions within an economy (Banerjee \& Duflo, 2005; Bowles, 2006). Several studies have been conducted on various types of government failure. These types of failure 'distort' private investment decisions because the protection levels of private productive activities are too high or too low. This causes the economy to depend on public policies. These failures also produce an insufficient and standardized supply of public goods; they do not foster coordination and cooperation among businesses, with the obvious consequence that they are unwilling to introduce innovations whose benefits are not completely internalized (Ciccone \& Matsuyama, 1996).

The last class of models explains poverty traps on the basis of agents' membership, in contexts where exchanges are assumed not to be regulated by market conditions alone, but by the entire set of social norms (ethical values, habitual behavior, shared mental models). The idea is that agents adopt behavior which is widespread within an economy, and if these behaviors are 'bad' they discourage 'good' ones. These poverty trap models highlight the fact that the long-run path of an economy in different local contexts depends on whether the initial conditions or innovative actions (and their agglomerative effects) prevail. In the first case, the unequal initial conditions imply the persistence of an unequal outcome, and the economy is trapped in a sub-optimal equilibrium. In the latter case, the long-term equilibrium depends on the complementarities activated by agents' expectations - which may be optimistic or pessimistic: "beliefs that a bad outcome will occur do come true in the sense that such beliefs precipitate bad outcomes" (Ray, 2000, p. 16) The complementarities among agents' expectations are of crucial importance because, if agents share the belief that all agents will shift from the traditional to the emerging sector, they will all be encouraged to take action and to invest immediately to obtain greater benefits from innovation.

\section{Bridging development and other-regarding preferences}

The hypothesis of a two-way causation between growth and human development recently proposed by Ranis et al. (2004) seems particularly suited to explaining how the third sector contributes to the activation and sustainability of a change process within an economy. According to this hypothesis, the third sector is an important institutional actor in intercepting and sustaining the link between economic growth and human development in both directions. For instance, the most recent literature on poverty traps highlights the reason why individuals are not always, and/or not all, able to exploit the advantages offered by the new opportunities in an economy.

The third sector, on one hand, favors the active participation of all agents in all markets and in the voluntary supply of public goods: it does so by furnishing welfare services with high relational content and goods of collective 
interest, social inclusion, quality in employment relationships and in the delivery of services, incentives to innovate governance models (internally and externally to non-profits). This contribution, carried out particularly by the productive component of the third sector (i.e., social cooperatives and social enterprises) has been largely documented across Western Europe, taking into account the features characterizing the development level and the institutional welfare policies in each country (EMES European Network, 1999; Defourny \& Nyssen, 2008).

On the other hand, the third sector promotes a culture of heterogeneity both in the motivations for economic action and in the consequent implementation of organizational models because it brings out other-regarding patterns of behavior (within a population) and, above all, fosters them by giving visibility and legitimacy to operational rules (on coordination, cooperation, reciprocity etc.) and to the results (often superior to the outcomes of market interactions in terms of both efficiency and social desirability). Referring once again to the increasing economic weight of the NPOs in the development process of Western European countries, the productive component of the third sector plays an effective role when intrinsic pro-social preferences and extrinsic monetary motivations come together, thus making more effective nonmonetary incentive mechanisms: in particular, the social mission affects the achievement of social goals, and, in turn, the economic capability reinforces the economic weight of the social mission. Naturally, isomorphic cases in the third sector must be taken into account: one hypothesis is the weakening of the mission compared to the profit scope; the other is the weakening of the entrepreneurship capabilities, leading to dependence on public subsidies. When these situations occur, the third sector's capability of sustaining the development of an economy in the long-run is weakened (EMES European Network, 1999; Defourny \& Nyssen, 2008).

Section 4.1, according to an extensive interpretation of the model developed by Ranis et al. (2004), considers the role of the third sector in the cumulative causation, in the direction running from EG to HD. It discusses the traps caused by the 'threshold effect' (i.e., the first class of models identified in Section 3.2) or by 'institutional failures' (the second class of trap models). Section 4.2 considers the link running from HD to EG, with reference to the trap created by the 'membership effect' (the third class of trap).

4.1 From growth to human development

The third sector's role, in the link running from growth to human development, lies at micro level, in that it occupies the spaces opened up by state and market failures: the third sector helps increase and diversify the composition of output and aggregate employment, so that it increases - in an egalitarian direction - and diversifies the choices available to agents in markets.

With reference to the productive component of non-profits, the recent rise and spread of the social enterprise in Europe (Borzaga \& Defourny, 2001) contributes firstly to satisfying the Keynesian macroeconomic condition for growth: namely change in the composition of aggregate demand in which services predominate (especially welfare services and goods of collective importance). Secondly, it sustains the system's level of production and 
productivity, for instance by making specific investments in human capital in new sectors, or by attracting financial resources and innovations (Lorentz \& Savona, 2007).

If the driving force behind the process of cumulative causation is the emergence of this productive component visible in the third sector's increasing contribution to GDP and employment, the process is virtuous if it activates propagation mechanisms. One of these mechanisms is indubitably the labor market: (i) investment in human capital for the creation of a pool of workers specialized in social management (fund-raising, social reporting, mission balance sheet, participative organization of human resources, social service provision, needs recognition, horizontal and vertical institutional networking with for-profit enterprises and public institutions); (ii) action against the depletion of human capital through the mobilization of specialized labor in voluntary organizations (unemployed doctors, women re-entering the labor market, etc.); (iii) the reintegration of disadvantaged persons into employment; (iv) the creation of a pool of specialized workers stimulates enterprises to innovate their production processes, and it increases demand for new skills, with positive impacts on recruitment/job-search costs and on the competitiveness of the third sector's production. The other propagator mechanism is the welfare services market: the increase in disposable income not only indirectly supports demand but also diversifies consumption patterns through the activation of new needs.

As suggested by models of the poverty trap caused by the 'threshold effect', the process is virtuous only if the benefits from the productive component of the third sector are substantial and persistent: that is, if they reach a 'minimum threshold' below which is not economically convenient to make specific investments and, conversely, above which workers and enterprises perceive and exploit this new opportunity for income and employment because the stock of capital accumulated in the sector yields increasing returns to scale on the investment (because, for instance, voluntary work is not undertaken by sporadic and isolated bodies but draws vitality from institutional complementarities with other productive and distributive actors).

The role of the third sector in the link running from growth to human development is also suggested by the models of the poverty trap caused by 'institutional failures': for instance, when prevalent in an economy are rules that protect rent-seeking behavior or exacerbate the unequal distribution of assets and, therefore, of decision-making power among agents. A mechanism that propagates the virtuous circle is redefinition of the rules governing access to the various markets so that advantage is taken of the new opportunities for active participation furnished by the emergence of the third sector's productive component: a striking example is the introduction of micro-credit for social cooperatives (and for social cooperatives with large female components) where the elements used to evaluate creditworthiness are the quality of the social services delivered, the participative nature of the productive model, and the ethical purpose of the production.

In this case, too, the equilibrium solution is not automatically virtuous, given reform of the institutional system in an egalitarian direction, because an increase in opportunities is not enough. In other words, formal rules of 
access to the market is not an incentive sufficient in itself to foster innovative models and spread them within a population.

\subsection{From human development to growth}

The multiplier and accelerator effect of income (and of employment), in the presence of a new composition of final demand, can explain some of the story (positive, indirect and/or direct pecuniary externalities in virtuous cases). Nevertheless, if the mechanism of cumulative causation goes no further, there is nothing new in the virtuous path which an economy can follow.

The crucial issue is whether the third sector can help form a new culture of civil cohabitation that generates (cooperative) outcomes of social interactions different from those assumed by the neoclassical paradigm of self-regarding preferences. The literature cited in Section 1 has amply documented the presence of both self-interested and other-regarding preferences in the collectivity; the key question concerns which of these behaviors predominates and the possible role of the institutions. As stressed in the literature (Bowles, 1988; Fehr \& Fischbacher, 2005), the economic institutions can greatly influence the structure of social relations, not only by heightening the effectiveness of norms but also by modifying the desirability of certain behaviors. The task of promoting and spreading behavioral models based on altruism and cooperation cannot be undertaken either by the market or by the state because, in the former everything is reduced to the exchange of equivalents, and in the latter to welfare transfers made possible by 'compulsory' contributions from citizens (Zamagni, 2005).

The third sector, by contrast, is not solely the expression of other-regarding preferences in the community. Above all, it demonstrates the efficacy of cooperative schemes and participation in collective action in particular circumstances: the aggregate, repeated and successful effects of non-profits in various domains can thus perform an important role as mechanisms which propagate a culture of cooperation, altruism and reciprocity by selecting, activating and supporting pro-social preferences (on this point, see also Borzaga, 2007). The third sector is, we maintain, precisely the institution which not only organizes, but is also more efficiently able to determine, the emergence and spread of cooperative patterns of behavior which might otherwise remain only sporadic and isolated.

The other part of the story, therefore, is explained by the distinctive role of the social enterprise as an institutional innovation for development in different forms and through different channels of emergence, adoption, success and diffusion which can be summarized as follows: (i) the nature of the output and the processes of production/delivery of welfare services and goods of social importance transmit a set of ethical values, cultural models, and psychological motivations in exchange, as well as not exclusively self-interested and monetary attitudes; (ii) the novelty with respect to instrumental rational choice is that 'values' and 'beliefs' are the origins and determinants of economic action and its performance: for instance, the opportunity-cost of time among 
work, leisure, and availability to others is altered; the free transfer of private knowledge is facilitated; non-hierarchical criteria for the division of labor are introduced; and active participation in markets is promoted as a right; (iii) the trust in oneself and others fostered by non-profits (Sacco \& Zarri, 2006) is an important input to the efficiency of the economic system and for the improvement of human development of a community (Coleman, 1988; Sen, 2000; Tabellini, 2007).

According to our interpretation, leaving out isomorphic cases, the third sector performs an important role in the process of cumulative causation (in the direction running from human development to growth), not so much because of the nature of the goods and services produced or because of the distribution of its benefits, but because it alters poverty trap phenomena due to the imitation and persistence of traditional forms of behavior (largely rentseeking and self-regarding) and characterized, moreover, by a low propensity to invest and innovate (as in the third category of poverty trap models).

\section{Concluding remarks: social preferences, local development and the role of the third sector}

Following a selective review of the literature on different theoretical approaches, the paper has identified the key ideas to explain, in the future, whether and how the third sector will impact on the development of different territorial contexts, and whether and how it can contribute to overcoming poverty trap phenomena.

Firstly, the literature on social preferences has highlighted that individual behaviors in society are very often motivated by other-regarding considerations. When individuals cooperate in their neighborhoods, in workplaces, in social organizations, etc., they contribute to building socially desirable equilibria. Activating and sustaining the deepest motivations of individuals is an important opportunity for democracies to solve problems connected to state and market failures (Ostrom, 2005; Fitoussi, 2004).

Secondly, the modern theory of development suggests two interpretations of the third sector as an institution of an economy: i) the effectiveness of the third sector depends on its 'local embeddedness' both in terms of economic activities and of the other actors making up the institutional framework; ii) in turn, this local embeddedness may be 'positive' or 'negative', meaning that it can trigger either a 'virtuous' or a 'vicious' circle, depending on the initial conditions captured by various types of market failures and coordination failures (poverty traps).

Preferences and territorial contexts evolve together, generating equilibria which may be either path-dependent or driven by optimistic expectations (Ray, 2000).

Hence, by giving a broad interpretation to the model of two-way causation between growth and development proposed by Ranis et al. (2004), the paper has highlighted the third sector's potential role in the development of the advanced economies: (i) the third sector is an important institution for 
development because, on the one hand, it contributes to modifying individual expectations, thus becoming one of an economy's 'social technologies' and increasing opportunities in terms of agents' income, employment and exchange, and on the other, it can activate strategic complementarities between agents (externalities); (ii) the third sector selects, activates and sustains values and behaviors such as the cooperation, trust in others and in oneself essential (and irreplaceable) to achieve results in terms of efficiency and growth. 


\section{References}

Acemoglu, D. \& Robinson, J.A. (2000). Political losers as a barrier to economic development. American Economic Review, 90 (2), 126-130.

Adserà', A. \& Ray, D. (1998). History and coordination failure. Journal of Economic Growth, 3, 267-276.

Andreoni, J. (1988). Why free ride? Strategies and learning in public good experiments. Journal of Public Economics, 37, 291-304 .

Andreoni, J. \& Miller, J.M. (2002). Giving according to GARP: an experimental test of consistency of preferences for altruism. Econometrica, 2, 737-753.

Atkinson, A.B. (1998). Poverty in Europe. Oxford: Basil Blackwell.

Azariadis, A. \& Drazen, D. (1990). Threshold externalities and development Economics. Quarterly Journal of Economics, 105, 501-526.

Banerjee, A. \& Duflo, E. (2005). Growth theory through the lens of development economics. In S.N. Durlauf , P. Aghion (Eds.), Handbook of growth economics, 1A (pp. 475-552). North Holland, Amsterdam, New York: Elsevier.

Bardhan, P. (2004). Scarcity, conflicts and cooperation. Essays in political and institutional economics of development. Cambridge: the MIT Press.

Becker, G. (1974). A theory of social interactions. Journal of Political Economy, 82, 1063-1093.

Ben-Her, A. \& Gui, B. (2003). The theory of nonprofit organizations revisited. In H.K. Anheier, A. Ben-Her (Eds.), The study of the nonprofit enterprise. Theories and approaches (pp. 3-26). New York: Kluwer Academic, Plenum Publishers.

Bolton, G. E. \& Ockenfels, A. (2000). A Theory of equity, Reciprocity and competition. American Economic Review, 100, 166-193.

Borzaga, C. \& Santuari, A. (2000). The Innovative trends in the non-profit sector in Europe: the emergence of social entrepreneurship. OECD/LEED Forum on Social Innovation.

Borzaga, C. \& Defourny, J. (Eds.). (2001). The emergence of social enterprise. London: Routledge.

Borzaga, C. (2000). The role of non profit sector in a local development: new trends. OECD Conference paper, 11-12 september 2000.

Borzaga, C. (2007). Dalle identità ai modelli di governance: le specificità dell'impresa sociale. ISSAN working paper no. 23, Università di Trento. 
Bowles, S. (1998). Endogenous preferences: the cultural consequences of markets and other economic institutions. Journal of Economic Literature, 36, 75-111.

Bowles, S. (2003). Coevolution of human behaviour and social institutions. Journal of Theoretical Psychology, 223, 135-147.

Bowles, S. \& Gintis, H. (2002). Social capital and community governance. The Economic Journal, 112, 419-436.

Bowles, S. \& Gintis, H. (2005). Social community, moral sentiments, and community governance. In H. Gintis, S. Bowles, R. Boyds, \& E. Fehr ( Eds.), Moral sentiments and material interests (pp. 379-398). Cambridge: The MIT Press.

Bowles, S. (2006). Institutional poverty traps. In S. Bowles, S.N. Durlauf, K. Hoff (Eds.), Poverty traps (pp. 116-138): Princeton : Princeton University Press.

Bowles, S., Durlauf, S.N. \& Hoff, K.( Eds.). (2006). Poverty traps. Princeton: Princeton University Press.

Camerer, C. \& Thaler, R. (1995). Ultimatum, Dictators, and manners. Journal of Economic Perspectives, 9 (2), 209-219.

Ciccone, A. \& Matsuyama, K. (1996). Start-up costs and pecuniary externalities as barriers to economic development. Journal of Development Economics, 49, 33-59.

Coleman, J. (1984). Introducing social structure into economic analysis. American Economic Review, 74 (2), 84-88.

Coleman, J. (1988). Social capital in the creation of human capital. American Journal of Sociology, 94, 95-120.

Defourny, J. \& Nyssen, M. (Eds.) (2008). Social enterprise in Europe: New trends and development. EMES working paper no 08/1.

Denzau, A.T. \& North, D.C.(1994). Shared mental models, Ideologies and institutions. Kyklos, 47, 3-31.

Durlauf, S.N. (2006). Groups, social influences and inequality: a memberships theory perspective on poverty traps. In H. Gintis et al. (Eds.), cit. (pp. 141-175).

Eggertsson, T. (1998). Limits to institutional reform. Scandinavian Journal of Economics, 100, 335-357.

EMES (1999). The emergence of social enterprise in Europe. A short overview. Bruxelles: Emes European Network.

Engermann, S.L. \& Sokoloff, K. (2000). History lesson: factor endowments and paths of development. Journal of Economic Perspectives, XIV (3), 217232. 
Esping-Andersen, G.( Ed.). (2002). Why we need a new welfare state. Oxford: Oxford University Press.

Falk, A. \& Fischbaker, U.(2005). Modelling strong reciprocity. In H. Gintis et al. (Eds.) cit. (pp. 193-214).

Fehr, E. \& Fischbaker, U. (2005). The economics of strong reciprocity. In Gintis H. et al. (Eds.) cit. (pp.151-192).

Fehr, E. \& Schmidt, K.M. (1999). A theory of fairness, Competition and cooperation. Quarterly Journal of Economics, 114, 817-868.

Fehr, E. \& Gatcher, S. (2000). Cooperation and punishment in public goods experiments. American Economic Review, 90, 980-994.

Fischbacher, U., Gatcher, S. \& Fehr, E. (2001). Are people conditionally cooperative from a public goods experiment. Economic Letters, 71, 397-404.

Fischbacher U., \& Gachter, S. (2008). Heterogeneous social preferences and the dynamics of free rising in public good experiments. CeDex discussion paper no. 2008-07.

Fitoussi, J.P. (2004). La democratie et le marchè. Pris : Editions Grasset \& Fasquelle.

Fong, C.M., Bowles, S. \& Gintis, H. (2005). Reciprocity and welfare state. In Gintis H. et al. (Eds.), cit. (pp. 277-303).

Forsyther, R., Horowitz, J.L., Savin, N.E., \& Sefton, M.(1994). Fairness in simple bargaining experiments. Games and Economic Behavior, 6, 347-369.

Frey, B.S. \& Oberolzer-Gee, F. (1997). The cost of price incentives: An empirical analysis of motivation crowding-out. American Economic Review, 87(4), 746-755.

Frey, B.S., Benz, M. \& Stutzer, A. (2004). Introducing procedural utility: not only what, but also how matters. Journal of Institutional and Theoretical Economics, 160 ( 3), 377-401.

Gintis, H., Bowles, S., Boyd, R. \& Fehr, E. (Eds.). (2005). Moral sentiments and material interests. Cambridge: The MIT Press.

Guth, W. \& Tietz, R. (1990). Ultimatum bargaining behaviour: A survey and comparison of experimental results. Journal of Economic Psychology, 11, 417-449.

Hirschman, A. O. (1958). The strategy of economic development. New Haven: Yale University Press.

Hodgson, J. (1993). Economics and evolution: Bringing life back into economics. Cambridge: Cambridge Polity Press.

Hoff, K. (2000). Beyond Rosenstein Rodan: The modern theory of coordination problem in development. In Proceedings of the annual Bank Conference on development economics (pp.145-176). Washington: The World Bank. 
Hoff, K. \& Stiglitz, J.E. (2000). Modern economic theory of development. In G.M. Meier \& J.E. Stiglitz, J.E. (Eds) Frontiers of development economics (pp. 389- 459). Oxford: Oxford University Press.

James, E. (1986). How nonprofit grow: a model. In S. Rose-Ackerman (Ed.), The economics of nonprofit institutions. Studies in structure and policy. New York, Oxford: Oxford University Press.

Kahan, D.M. (2005). The logic of reciprocity. In H. Gintis et al. (Eds.), cit. (pp. 339-378).

Ledyard, J.O. (1995). Public goods: A survey of experimental research. In J.H. Kagel \& A.E. Roth (Eds.), Handbook of experimental economics (pp. 111-194). Princeton: Princeton University Press.

Kurzban, R. \& Houser, D. (2001). "Individual differences in cooperation in a circular public goods game. European Journal of personality, 15, 37-52.

Levine, D. (1998). Modelling altruism and spitefulness in experiments. Review of Economic Dynamics, 1, 593-622.

Lorentz, A. \& Savona, M. (2007). Evolutionary micro-dynamics and changes in the economic structure. Max Plank Institute, working paper no.717.

Matsuyama, K. (1996). Economic development as coordination problems. In M. Aoki, H. Kim \& M. Okuno-Fujwara (Eds.), The role of government in East Asian development (pp. 134-159). Oxford: Oxford University Press.

Myrdal, G. (1968). Asian drama: An inquiry into the poverty of nations. New York: Twentieth Century Fund.

Nelson, R.R. \& Sampat, B.N. (2001). Making sense of institutions as a factor of shaping economic performance. Journal of Economic Behaviour and Organization, 44, 31-54.

North, D.C. (1990). Institutions, institutional change and economic performance. Cambridge: Cambridge University Press.

Ostrom, E. (2005). Policies that crowd out reciprocity and collective actions. In H. Gintis et al. (Eds.), cit. (pp.253-276).

Putnam, R.D. (1993). Making democracy work. Civic traditions in modern Italy. Princeton: Princeton University Press.

Putnam, R.D. (1995). Bowling alone: America's declining social capital. Journal of Democracy, 6 (1), 65-78.

Rabin, M. (1993). Incorporating fairness into game theory and economics. American Economic Review, 83 (5),1281-1302.

Ranis, G., Boozer, M., Stewart, F. \& Suri, T. (2004). Paths to success: the relationship between human development and economic growth. Economic Growth Center, Yale University, discussion paper no.874.

Ray, D. (2000). What's new in development economics? The American Economist, 44, 3-16. 
Reingen, P.H. (1982). Test of a list procedure for inducing compliance with a request to donate money. Journal of Applied Psychology, 67, 110.

Rodrik, D., Subramanian, A. \& Trebbi, F. (2004). Institution rule: The supremacy of institutions over geography and trade integration. NBER working paper no 305.

Rose-Ackerman, S. (1996). Altruism, Nonprofits, and economic theory. Journal

of Economic Literature, 34, 701-728.

Roth, A.E., Prasnikar, N., Okuno-Fujwara, M. \& Zamir, S. (1991). Bargaining and market behavior in Jerusalem, Ljubljana, Pittsburgh and Tokyo: an experimental study. American Economic Review, 81 (5), 10681095.

Rutherford, M. (2001). Institutional economics: Then and now. The Journal of Economic Perspectives, 15, 173-94.

Sacco, P.L. \& Zarri, L.(2006). Perché esiste il settore non profit? Filosofia e Questioni Pubbliche, 1, 43-70.

Sacconi, L. \& Grimalda, G. (2005). L'insorgenza dell'impresa sociale: il ruolo delle preferenze ideali e del conformismo. Impresa Sociale, 4 (74), 106129.

Sacconi, L. \& Faillo, M. (2005). Impresa sociale efficiente e complementarietà tra preferenze conformiste e ricerca della reputazione. Impresa Sociale, 4 (74), 153-183.

Salomon, L.M. \& Anheier, H.K. (1999). Global civil society. Dimensions of the nonprofit Sector. Baltimora: The Johns Hopkins Centre for Civil Society Studies.

Schotter , A. (1986). The evolution of rules. In R. Langlois (Ed.), Economics as a process: Essays in the New Institutional Economics. Cambridge, MA: Cambridge University Press.

Sen, A. (1999). Development as freedom. New York: Albert A. Knopf.

Snaveley , K. (1990). Governmental policies to reduce tax evasion: Coerced behaviour versus services and values development. Policy Sciences, 23, 5772.

Tabellini, G. (2007). Culture and institutions. CESifo, Munchen, working paper no 1492.

Valentinov, V. L. (2007). Some reflections on the transaction cost theory of nonprofit organisations. Zeitschrift für öffentliche und Gemeinwirtschaftliche Unternehmen, 30 (1), 52-67.

Venables, J. \& Burgess, R.(2004). Toward a microeconomics of growth. World Bank Policy Research, working paper no. 3257.

Zamagni, S. (1998). Non-profit come economia civile. Bologna: II Mulino. 
Zamagni, S. (2005). Gratuità ed agire economico: il senso del volontariato. AICCON working paper no. 9.

Young, D.R. (1980). Entrepreneurship and the behavior of nonprofit organizations: elements of a theory. PONPO Working Paper 4. Yale University. 


\title{
CELPE's Discussion Papers
}

\author{
2008109 Giorgia IOVINO \\ Gis, ricerca geografica e pianificazione urbanistica: un'applicazione \\ sul centro storico di Benevento \\ 2008108 Bruna BRUNO \\ La donna flessibile e il lavoro opportuno \\ 2008107 Damiano FIORILLO \\ Offerta di Attività Gratuita in Italia: una analisi micro-econometrica \\ 2007, 106 Shane Niall O'HIGGINS, Marcello D'AMATO, Floro Ernesto \\ CAROLEO, Adriana BARONE \\ Gone for Good? Determinants of School Dropout in Southern Italy \\ 2007, $105 \quad$ Ugo COLOMBINO, Annamaria NESE \\ Preference Heterogeneity in Relation to Museum Services \\ 2007, 104 Giuseppe CELI, Mario SPORTELLI \\ Harrod's Dynamics and the Kaldor-Thirlwall Export-led Growth \\ 2007, 103 Francesca BETTIO, Fernanda MAZZOTTA, Giovanni SOLINAS \\ Costs and prospects for home based Long Term Care in Northern \\ Italy: the Galca survey \\ 2007, 102 Lisa CROSATO, Sergio DESTEFANIS, Piero GANUGI \\ Technology and Firm Size Distribution: Evidence from Italian \\ Manufacturing \\ 2007, 101 Guglielmo Maria CAPORALE, Alexandros KONTONIKAS \\ The Euro and Inflation Uncertainty in the european Monetary Union \\ 2006, 100 Francesco Paolo VOLPE \\ Principio democratico e giustizia nell'amministrazione \\ 2006, $99 \quad$ Niall O'HIGGINS \\ Still With Us After All of These Years: Trends in Youth Labour Market \\ Entry, Home-Leaving And Human Capital Accumulation in Italy 1993- \\ 2003 \\ 2005, 98 Floro Ernesto CAROLEO, Gianluigi COPPOLA \\ The Impact of the Institutions on Regional Unemployment Disparities \\ 2005, 97 Carlo ALTAVILLA, Antonio GAROFALO, Concetto Paolo VINCI \\ Is the Discouraged Worker Effect Time-Varying? \\ 2005, 96 F. BUSATO, B. CHIARINI, P. DE ANGELIS, E. MARZANO \\ Capital Subsidies and Underground Production
}


2005, 95 Lucio Valerio SPAGNOLO, Mario CERRATO

No euro please, We're British!

2005, 94 Roberto BASILE, Mauro COSTANTINI, Sergio DESTEFANIS

Unit root and cointegration tests for cross-sectionally correlated panels. Estimating regional production functions

2005, 93 Sergio DESTEFANIS, Raquel FONSECA

Matching Efficiency and Labour Market Reform in Italy. A

Macroeconometric Assessment

2005, 92 Cesare IMBRIANI, Antonio LOPES

Banking System Efficiency and the Dualistic Development of the Italian Economy in the Nineties

2005, 91 Carlo ALTAVILLA, Antonio GAROFALO, Concetto Paolo VINCI Designing the Optimal Lenght of Working Time

2005, 90 Marco MANACORDA, Barbara PETRONGOLO

Regional Mismatch and Unemployment: Theory and Evidence from Italy, 1977-1998

2004, 89 Roberta TROISI

Teoria dell'impresa e responsabilità parapenale: le implicazioni organizzativo-gestionali

2004, 88 Roberta TROISI

Enti non profit: tipologie ed opzioni organizzative

2004, $87 \quad$ Lavinia PARISI

La povertà: una rassegna sul confronto tra due approcci. Capability vs. Unidimensionalità

2004, $86 \quad$ Giuseppe CELI

Quality Differentiation, Vertical Disintegration and the Labour Market Effetcs of Intra-Industry Trade

2004, $85 \quad$ Niall O'HIGGINS

Recent Trends in Youth Labour Martkets and Employment Policy in Europe and Central Asia

2004, 84 Carlo ALTAVILLA, Floro Ernesto CAROLEO

Evaluating Asimmetries in Active Labour Policies: The Case of Italy

2004, 83 Floro Ernesto CAROLEO, Francesco PASTORE

La disoccupazione giovanile in Italia. La riforma dei sistemi

d'istruzione e di formazione professionale come alternativa alla

flessibilità numerica per accrescere l'occupabilità

2004, 82 Francesco PASTORE, Izabela MARCINKOWSKA

The Gender Wage Gap among Young People in Italy 
2004, $81 \quad$ Elisabetta MARZANO

Dual Labour Market Theories And Irregular Jobs: IsThere a Dualism Even in The Irregular Sector?

2004, $80 \quad$ Corrado ANDINI

Unemployment and Welfare Partecipation in a Structural VAR:

Rethinking the 1990s in the United States

2004, 79 Floro Ernesto CAROLEO

Fondamenti teorici della rigidità salariale nell'ambito dei "Non Market clearing Models"

2004, 78 Adalgiso AMENDOLA, Floro Ernesto CAROLEO, Gianluigi COPPOLA

Regional Disparities in Europe

2003, 77 Fernanda MAZZOTTA

Flessibilità, povertà e istruzione: un approccio Sen - istituzionale

2003, $76 \quad$ Adalgiso AMENDOLA, Annamaria NESE

Mobilità intergenerale nel livello d'istruzione nella società femminile italiana ed endogenità de titolo di studio in un modello di partecipazione alla Forza Lavoro.

2003, $74 \quad$ Antonio LOPES

Innovazione nel Sistema Creditizio del Mezzogiorno negli Anni Novanta

2003, 73 Sergio DESTEFANIS, Vania SENA

Public Capital and Total Factor Productivity New Evidence from the Italian Regions

2003, 72 Giuseppina AUTIERO, Bruna BRUNO

Social Preferences in Wage Bargaining: a Neocorporatist Approach

2003, 71 Gianluigi COPPOLA, Maria Rosaria GAROFALO, Fernanda MAZZOTTA

Industrial Localisation and Economic Development. A Case Study

2002, 70 Francesco GIORDANO, Fernanda Mazzotta

Salario di Riserva, Probabilità di Occupazione ed Efficacia dell'Istruzione Universitaria: un'Analisi sugli Studenti dell'Università di Salerno

2002, 69 Giuseppe RUSSO

Istituzioni del Mercato del Lavoro e Occupazione: dai Costi di Aggiustamento all'Appropriabilità

2002, 68 Floro Ernesto CAROLEO, Francesco PASTORE

Training Policy for Youth Unemployed in a Sample of European Countries 
2002, 67 Maria Rosaria GAROFALO, Maria Rosaria SUPINO

II Disegno Normativo del Welfare Municipale in Italia come Strumento per lo Sviluppo Economico e l'Allargamento delle Opportunità

Occupazionali. Una Lettura Neoistituzionale della L. 328/00

2002, $65 \quad$ Pietro SENESI

Cyclical dynamics under continuous time equilibrium

2001, 64 Marcello D'AMATO, Vincenzo GALASSO

E' la Riforma Dini Politicamente Sostenibile?

2001, 63 Sergio DESTEFANIS, Ornella Wanda MAIETTA

Assessing the Productive Efficiency of Non-Profit Organisations: a

Comparative Analysis

2001, 62 Floro Ernesto CAROLEO, Francesco PASTORE

How fine targeted is ALMP to the youth long term unemployed in Italy?

2001, $61 \quad$ Paolo COCCORESE

Strategic Advertising for Entry Deterrence Purposes

2001,60 Alessandra AMENDOLA

Modelling Asymmetries in Unemployment Rate

2001, 59 Sergio DESTEFANIS

Differenziali Territoriali di Produttività ed Efficienza negli Anni '90: $i$

Livelli e l'Andamento

2001, 58 Giuseppina AUTIERO, Fernanda MAZZOTTA

Job Search Methods: the Choice between the Public and the Private Sector

2001, 57 Giuseppina AUTIERO, Bruna BRUNO, Fernanda MAZZOTTA

A Correspondence Analysis of Labour Market Institutions

2000, $56 \quad$ Giuseppina AUTIERO

Governmental Organized Learning and Coordination Problems: The case of Japan in 1950s

2000, 55 Giuseppina AUTIERO, Fernanda MAZZOTTA

The Choice of Search Methods: Some Empirical Evidence from Italy

2000, $54 \quad$ Giuseppe CELI

The Impact of International Trade on Labour Markets. The Case of Outward Processing Traffic between the European Union and Central Eastern European Countries.

2000, 53 Giuseppe RUSSO, David VEREDAS

Institutional Rigidities and Employment on the Italian Labour Market: the Dynamic of the Employment in the Large Industrial Firms. 
2000, 52 Floro Ernesto CAROLEO

Le Politiche per l'Occupazione in Europa: una Tassonomia Istituzionale

2000, $51 \quad$ Andrew NEWELL, Francesco PASTORE

Regional Unemployment and Industrial Restructuring in Poland

1999, $50 \quad$ Giuseppe CELI, Alasdair SMITH

Quality Differentiation and the Labour Market Effects of International Trade.

1999, $49 \quad$ Giuseppe CELI

Vertical and Horizontal Intra-Industry Trade: What is the Empirical

Evidence for the UK?

1999, 48 Cesare IMBRIANI, Filippo REGANATI

Productivity spillovers and regional differences: some evidence on the italian manufacturing sector.

1999, 47 Adalgiso AMENDOLA, Annamaria NESE

L'impatto del background familiare sul livello d'istruzione dei figli.

1998, $46 \quad$ Adalgiso AMENDOLA, Annamaria NESE

Mobilità intergenerazionale nella società femminile italiana.

1998, 45 Floro Ernesto CAROLEO, Fernanda MAZZOTTA

Youth Unemployment and youth employment policies in Italy.

1997, $44 \quad$ Annamaria NESE

Mobilità intergenerazionale in Italia

1997, 43 Adriana BARONE, Concetto Paolo VINCI

Fairness: un concetto relativo nell'analisi del mercato del lavoro

1997, 42 Adriana BARONE, Concetto Paolo VINCI

Wage differentials and factor intensity reversals

1997, 41 Rosa CAPOLUPO

L'ipotesi di convergenza nel recente dibattito sulle teorie della crescita

1997, $40 \quad$ Rosa CAPOLUPO

Endogenous Vs exogenous models of growth: the convergenze debate

1997, 39 Fernanda MAZZOTTA, Annamaria NESE

Transizioni "In and Out" il mercato del lavoro in Italia: un'analisi microeconometrica 
1997, 38

1997, 37 Maria Rosaria GAROFALO, Bruna BRUNO

Equivalenza istituzionale" dei modelli di contrattazione sul salario: oltre il dibattito tra centralizzazione e decentramento

1997,36

Adalgiso AMENDOLA, Floro Ernesto CAROLEO, Gianluigi COPPOLA

Differenziali territoriali nel mercato del lavoro e sviluppo in Italia

1996, 35 Adalgiso AMENDOLA

Istituzioni e mercato del lavoro. Deregolazione, occupazione e paradigma istituzionale

1996, 33 Annamaria NESE

Modelli microeconometrici per l'analisi della domanda abitativa

1996, 32 Annamaria NESE

Test semiparametrici per modelli parametrici

1996, $31 \quad$ Giuseppe CELI

Vertical intra-industry trade and skill intensity in Europe: a cross sector analysis

1996, $30 \quad$ Sergio DESTEFANIS

Nominal rigidities and real activity. A cross-industry analysis for Italy, 1951-93

1996, 29 Cesare IMBRIANI, Filippo REGANATI

International technology transfer into the italian manufacturing sector

1996, 28 Stefania di SERAFINO, Alberto GANDOLFI

The choice of the Government optimal procurement mechanism: the first-price sealed bid auction with one and/or two winners.

1996, 27 Raul de LUZENBERGER

Redistribution, and public debt with liquidity constraints

1996, 26 Bruno CHIARINI

Un modello VAR per la domanda di lavoro

1995, 25 Maria Rosaria CARILLO, Alberto ZAZZARO

Innovazione tecnologica e distruzione di capitale umano in un modello neo-shumpeteriano di crescita.

1995, 24 Raul de LUZENBERGER

Macroeconomia e politiche redistributive: il caso di vincoli di liquidità

1995, 23 Annamaria NESE

Tenure choice and demand for housing in Italy 
1995, 21 Sergio DESTEFANIS, Michele LA ROCCA, Cosimo VITALE Forecasting train ticket sales with linear model-based approaches and with edats

1995, 20 Stefania di SERAFINO

Bounded rationality and incomplete contracts

1995, 19 Adalgiso AMENDOLA, Floro E. CAROLEO, Maria Rosaria GAROFALO

Istituzioni, mercato del lavoro e decentramento delle decisioni.

1995, 18 Niall O'HIGGINS

Why did the youth training scheme reduce reduce the wages of young people? A story of human capital formation, reservation wages and job offers.

1994, 17 Antonio CARDONE

Misure di efficienza: alcuni aspetti teorici

1994, 16 Maria Rosaria GAROFALO, Luisa ZANCHI

Neo-corporativismo, centralizzazione e dispersione inter-settoriale dei salari.

1994, $15 \quad$ Sergio DESTEFANIS

Allowing for frequency of negotiation in the aggregate wage equation. A study for italian manufacturing, 1973/92.

1994, 14 Marcello D'AMATO

Tariffs for a foreign industry with market power under incomplete information on demand

1994, 13 Raul DE LUZENBERGER, Cesare IMBRIANI, Giancarlo MARINI Sustainability Issues in the process of European Integration

1994, 12 Riccardo MARSELLI, Antonio CARDONE Interdipendenza tra regioni: un'analisi su dati di Panel

1993, 11 Adriana BARONE, Concetto Paolo VINCI Dilemma del prigioniero e persistenza della disoccupazione involontaria

1993, 10 Maria Rosaria CARILLO Mutamenti strutturali ed offerta di lavoro.

1993, 9 Niall O'HIGGINS

The effectiveness of YTS in Britain: an analysis of sample selection in the determination of employment and earnings 
1993, $8 \quad$ Giuseppe CELI

Politiche valutarie ed integrazione commerciale: l'esperienza dello SME negli anni '80

1992, 7 Paolo COCCORESE

Attività innovativa e configurazione industriale

1992, 6 Maria Rosaria GAROFALO, Gian Luigi CORINTO

La Razionalità dell'Allocazione del Tempo di Lavoro in Agricoltura.

Con un'Applicazione Empirica ad un Sistema Locale attraverso la $P L .$.

1992, 5 Adalgiso AMENDOLA, Maria SCATTAGLIA

Disoccupazione e Tassi di Attività nel Mezzogiorno

1992, 4 Floro Ernesto CAROLEO

La Disoccupazione Strutturale

1991, 3 Giovanni URGA

Dynamic Models of Labour Demand in the Italian Industrial Sector: Theories and Evidence from Panel Data

1991, $2 \quad$ Adalgiso AMENDOLA

Teoria dei Contratti Impliciti. Rigidità del Salario e Disoccupazione

1991, 1 Guido CELLA

Sulla Integrazione Produttiva Interregionale: il Caso del Mezzogiorno 
CELPE - Centro di Economia del Lavoro e di Politica Economica Università degli Studi di Salerno

Depositato ai sensi di Legge 